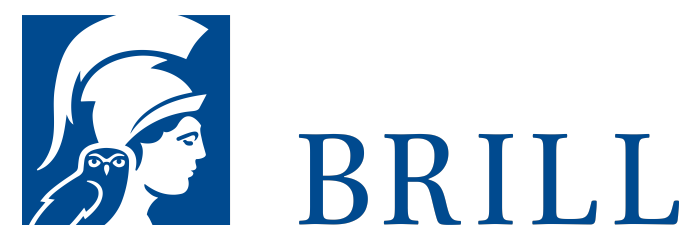

\section{Ärztliches Urteilen bei entscheidungsunfähigen Schwerkranken}

Geschichte -- Theorie -- Ethik

Author: Monika Bobbert

Wenn wir durch einen Unfall oder eine nicht heilbare Erkrankung in eine lebensbedrohliche Krise geraten, sind wir stärker als sonst auf Andere angewiesen. Wenn wir uns nicht mehr äußern können, womöglich auf längere Sicht nicht mehr urteilsfähig sind, müssen Andere, in erster Linie die behandelnden Ärzte und Angehörigen, einen guten Weg in Bezug auf Diagnose und Therapie finden. Rasch kann die Frage aufkommen, an welchen ethischen Normen und Kriterien man sich orientieren soll, wenn ein Patient sein Recht auf Selbstbestimmung nicht mehr wahrnehmen kann und sich auch keine schriftliche Vorausverfügung und kein "mutmaßlicher Wille" zuverlässig feststellen lassen. Ausgehend von historischen, empirisch-sozialwissenschaftlichen und theoretischen Überlegungen zur ärztlichen Praxis werden ethische Argumente auf ihre Tragfähigkeit hin geprüft. Im Zentrum des Buchs stehen u.a. die Unterscheidung von Tun und Unterlassen, die Bewertung von Lebensqualität und Leiden, die argumentative Kraft von Konzepten wie "medizinische Nutzlosigkeit" "künstliche" oder "außerordentliche" Mittel und "infauste" Prognose sowie der Stellenwert von Wünschen und Bedürfnissen Angehöriger.

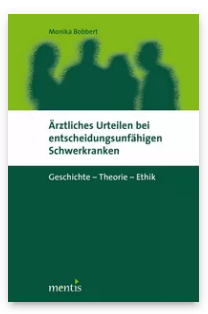

Pages: 564

Seiten

Language:

German

Subjects:

General,

Philosophy

Publisher: Brill | mentis

E-Book (PDF)

Released online:

O1 Jan 2013

ISBN: $978-3^{-}$

95743-956-7

List price

Paperback

Publication date:

o1 Jan 2013

ISBN: 978-3-

89785-796-4

List price 
For more information see brill.com

Order information: Order online at brill.com +44330 333 0049 | customerservices@brill.com Submission information: brill.com/authors

Titles published by Brill | Fink, Brill | mentis or Brill | Schöningh: +49(o)715413279216| brill@brocom.de 